\title{
Antimicrobial Activity of Benzimidazoles Derivatives
}

\author{
N. Srinivasa Rao, K. Lakshmi, S. Mohan, V. Nagalakshmi
}

\begin{abstract}
The anti-microbial action of benzimidazole of ampicillin, was examined in Vitro beneath a specific conditions, utilizing the disc diffusion method, against different gram-positive and gram-negative pathogenic microorganisms such as Bacillus cereus, Staphylococcus aureus Pseudomonas aeruginosa and Escherichia Coli. An arrangement of these compounds were arranged and have appeared to hinder phthogenic development, the range of the zone of restraint. The zone of Obstacles of compounds founds from $7 \mathrm{~mm}^{2}$ to $46 \mathrm{~mm}^{2}$ Among the synthesized compounds in common. 6-Methoxy- $N$-phenyl1H-benzo [d]imidazol-2-amine(1c, zone of inhibition $9 \mathrm{~mm}^{2}$ at 40 $\mu \mathrm{g} / \mathrm{ml}$ against Escherichia coli) and 6-Chloro- $N$-phenyl-1H-benzo [d]imidazol-2-amine (1d, zone of inhibition $18 \mathrm{~mm}^{2}$ at $40 \mu \mathrm{g} / \mathrm{ml}$ against Bacillus cereus) have appeared great movement. While $1 \mathrm{j}$, zone of inhibition $20 \mathrm{~mm}^{2}$ at $40 \mu \mathrm{g} / \mathrm{ml}$ ), and (1i, zone of inhibition $20 \mathrm{~mm}^{2}$ at $40 \mu \mathrm{g} / \mathrm{ml}$ ) were found to be displayed directly to great action against Bacillus cereus and Escherichia coli. 1p did not appear any movement against Staphylococcus aureus .1e did not appear any movement against Escherichia Coli and Staphylococcus aureus.The results have shown clearly that the contribution of ele ctron -donation and electron- withdrawal to the aromatic ring inc reases antibacterial activity. Target benzimidazolessamples showe d antibacterial \& reference antibiotic ampicillin in vitro.

Keywords: Anti-microbial, Benzimidazoles, Inhibiting zone, ampicillin
\end{abstract}

\section{INTRODUCTION}

$\mathrm{B}$ Benzimidazole [1] and 2-aminobenzimidazole moieties are important compounds due to their significance showed in biological sciences and therapeutic. These molecules can be used in other applications like Nmethyl-D-aspartate (NMDA) antagonist,[2] factor Xa(FXa) inhibitor,[3] poly(ADPribose) polymerase (PARP) inhibitor,[4] neuropeptide YY1 receptor antagonist, [5] non-peptide thrombin inhibitor,[6] preparation of dyes and polymers which are strong tolerance of temperature these are showing anti-inflammatory, antimicrobial and antibacterial activities also. Hence, traditional methods and C-N cross-coupling in the presence of transition metals have been developed for the preparation of benzimidazole.

Revised Manuscript Received on July 15, 2020

* Correspondence Author

Dr. Srinivasa Rao Nathani*, Department of Chemistry, Bapatla Engineering College, Bapatla, India. E-mail: nathanisrinivasarao@gmail.com

Dr. K. Lakshmi, Bapatla Municipality, Ward women Protection Secretary, Bapatla, India. E-mail: lakshmisrinivas41@gmail.com

Dr. Mohan Seelam, Department of Chemistry, Bapatla Engineering College, Bapatla, India. E-mail: seelam.mohan123@gmail.com

Dr. V. Nagalakshmi, Department of chemistry, Ch.S.D.St.Theresa's College for Women(A), Eluru, India. E-mail: nlcheruvu@gmail.com

(c) The Authors. Published by Blue Eyes Intelligence Engineering and Sciences Publication (BEIESP). This is an open access article under the CC BY-NC-ND license (http://creativecommons.org/licenses/by-nc-nd/4.0/)
In this context, we wish to describe an efficient synthetic route for the preparation of benzimidazoles through three steps in one pot. In addition, synthesized benzimidazole compounds were screened for checking the antimicrobial activity using disc diffusion method.

\section{ANTIMICROBIAL ACTIVITY}

\section{A. Preparation of Suspension of Bacteria}

Two $\mathrm{ml}$ of $10 \%$ Sodium Chloride $(0.85 \% \mathrm{w} / \mathrm{v})$ were taken in the sample cell and after that closed with cotton. Wiped off with filter paper by cello tape. Sample cell were put in an autoclave for sterilization for 20lbs for $30 \mathrm{~min}$. One or two colonies of microorganisms sub cultured bacteria from the bacterial plate. Colonies were soluble in $10 \%$ sodium chloride solution with stirring. The sample cell was stamped and includes more colonies in the event that required.

\section{PROCEDURE FOR SENSITIVITY TEST}

\section{A. Arrangement of Muller Hinton Agar Plates}

$4.0 \mathrm{mg}$ Muller Hinton agar media was dissolution in $120 \mathrm{~mL}$ refined water in $250 \mathrm{~mL}$ RB Flask with mixing (For the arrangement of four plates) and after that closed with cotton, Wiped off with filter paper by cello tape. Sterilization for 20 lbs for $30 \mathrm{~min}$. After autoclaving, heat the $25-30 \mathrm{~mL}$ of media was placed on a petridish plate.. The media remains as solid in petri disk. After that, The plate was kept in incubators for drying to remove water vapor. Now Agar plate was prepared for utilize.

\section{B. Compounds solution preparation}

One mg of synthesized benzimidazoles sample soluble in dimethyl sulfoxide and polyethylene glycol in the proportion of 1:10 in the test tube vertex blending warmed. A code number is given to sample tube. With the support of the marker, the organized plate was divided into four quadrants. Every quadrant was given the same code as the test tube code containing the arrangement of the compound. One plate was once swabbing from one bacterial suspension with the help of a cotton swab. With the help of smaller scale pipette, 20-25 $\mu$ l arrangement of benzimidazoles compound used to be dropped on identical code of the quadrant as given on the sample cell containing an association of the benzimidazoles compound. All benzimidazoles sample plates were put in the hatchery to bring forth for 18-24hrs. The plates were seen after 18-24 hrs. In the event the particular benzimidazole compound was touchy for particular microscopic organisms.

Blue Eyes Intelligence Engineering and Sciences Publication (C) Copyright: All rights reserved.

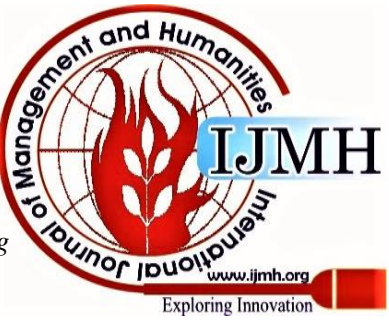




\section{Antimicrobial Activity of Benzimidazoles Derivatives}

At that point development was found in the entire plate but where the arrangement of the compound was dropped. In the event that the particular benzimidazole compound was not touchy for particular microscopic organisms. At that point, development was found in entirety plate counting where the arrangement of the compound was dropped.

Bacillus cereus, Staphylococcus aureus, Pseudomonas aeruginosa and Escherichia Coli species was investigated.

\section{Reference and Control}

The reference was anti-microbial in nature.Ampicillin has b een selected as the standard for all bacterial species The control test comprises a plate of setting agar on to which microorganism blended in a parcel as detailed.

\section{Aseptic conditions}

The chamber comprises of a wooden box ( $2 \mathrm{~m} \times 2 \mathrm{~m} \times 0.5 \mathrm{~m}$ ) the entrance washed with $75 \%$ alcohol and illuminated with short-wave ultra violet light for one hour.

\section{E. Antibacterial Activity}

The in vitro antibacterial action of Schiff bases of ampicillin used to be inspected against gram-positive bacteri a like. (Bacillus cereus (MTCC 430), Staphylococcus aureus (MTCC 3160) and gram-negative bacteria (Pseudomonas aeruginosa (MTCC 424), and Escherichia Coli (MTCC 40) .Relults are summarized in Table-1 in conjunction with standard medicine.
All analogues, showed up, comparable antibacterial activity at the, estimations $250 \mu \mathrm{g} / \mathrm{ml}$ against all the tested strains. Results indicate that compounds $1 \mathrm{~h}$ and $1 \mathrm{j}$ appeared most extreme action against Escherichia Coli (zone of inhibition=48 $\mathrm{mm}^{2}$ and $42 \mathrm{~mm}^{2}$ respectively and MIC=30 $\mu \mathrm{g} / \mathrm{ml}$ at the dose of of Schiff $250 \mu \mathrm{g} / \mathrm{ml}$ ) in comparison to other strains utilized by us .

\section{RESULTS AND SISCUSION}

The results (Fig-1) of antibacterial action uncovered that most of the synthesized compounds appeared good activity against Bacillus cereus Staphylococcus aureus, Pseudomonas aeruginosa, and Escherichia Coli. In general $\mathbf{1 g}$ and $\mathbf{1 j}$ have appeared great movement against chosen strains, while $\mathbf{1} \mathbf{i}$, and $\mathbf{1} \mathbf{j}$ were found to be shown directly to great activity against Staphylococcus aureus and Bacillus cereus. Shockingly $1 \mathrm{~h}$ did not appear any activity against Escherichia Coli and Bacillus cereus. 1e did not appeared any activity against Bacillus cereus and Escherichia Coli. The results clearly appeared that the commitment of electron donating and electron withdrawing groups on aromatic ring increasing the antibacterial activity.

Table 1: Physicochemical properties of the benzimidazoles (1-a to 1-k)

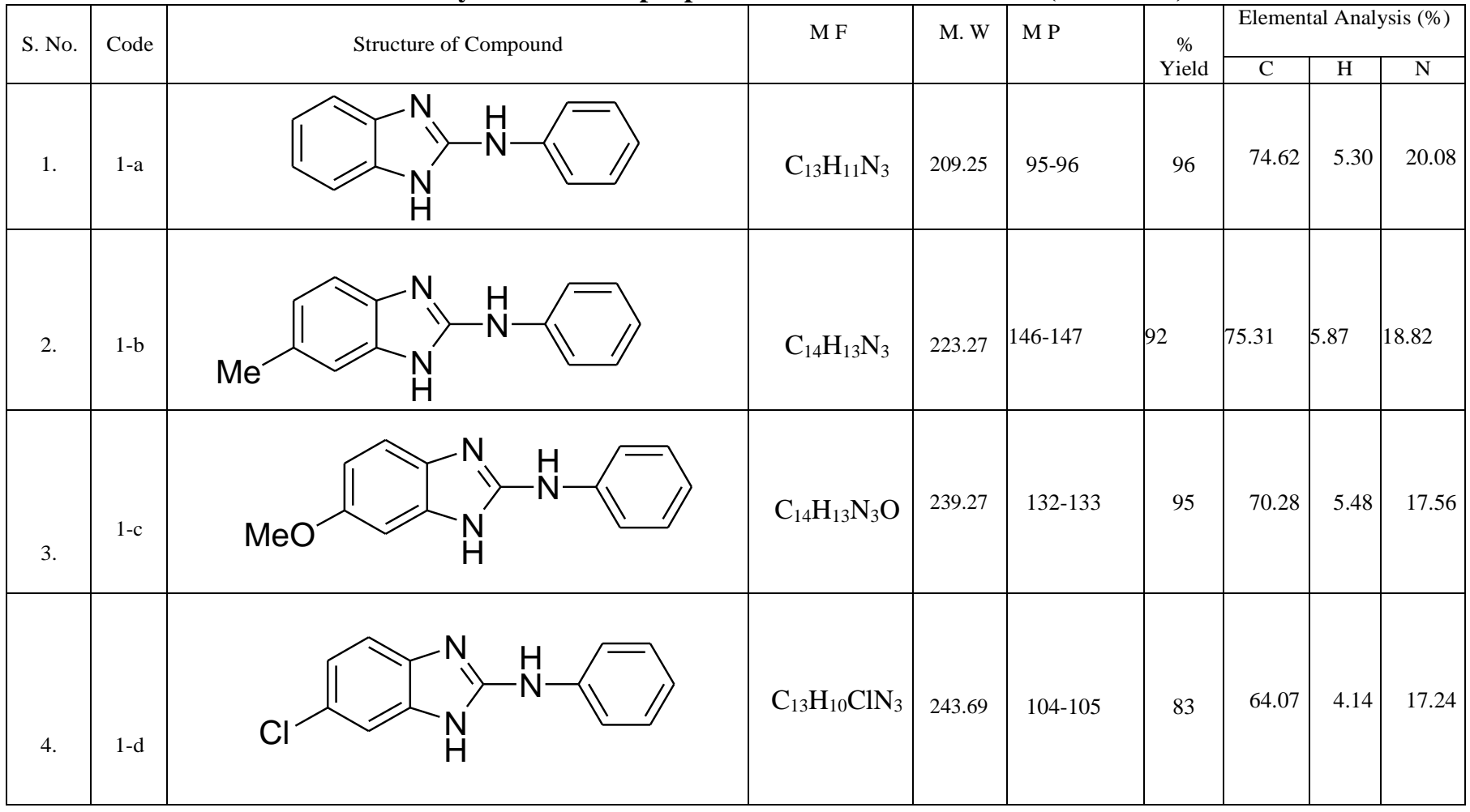

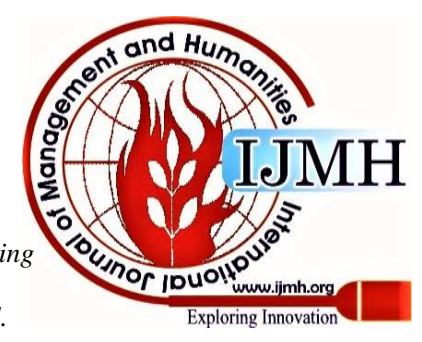




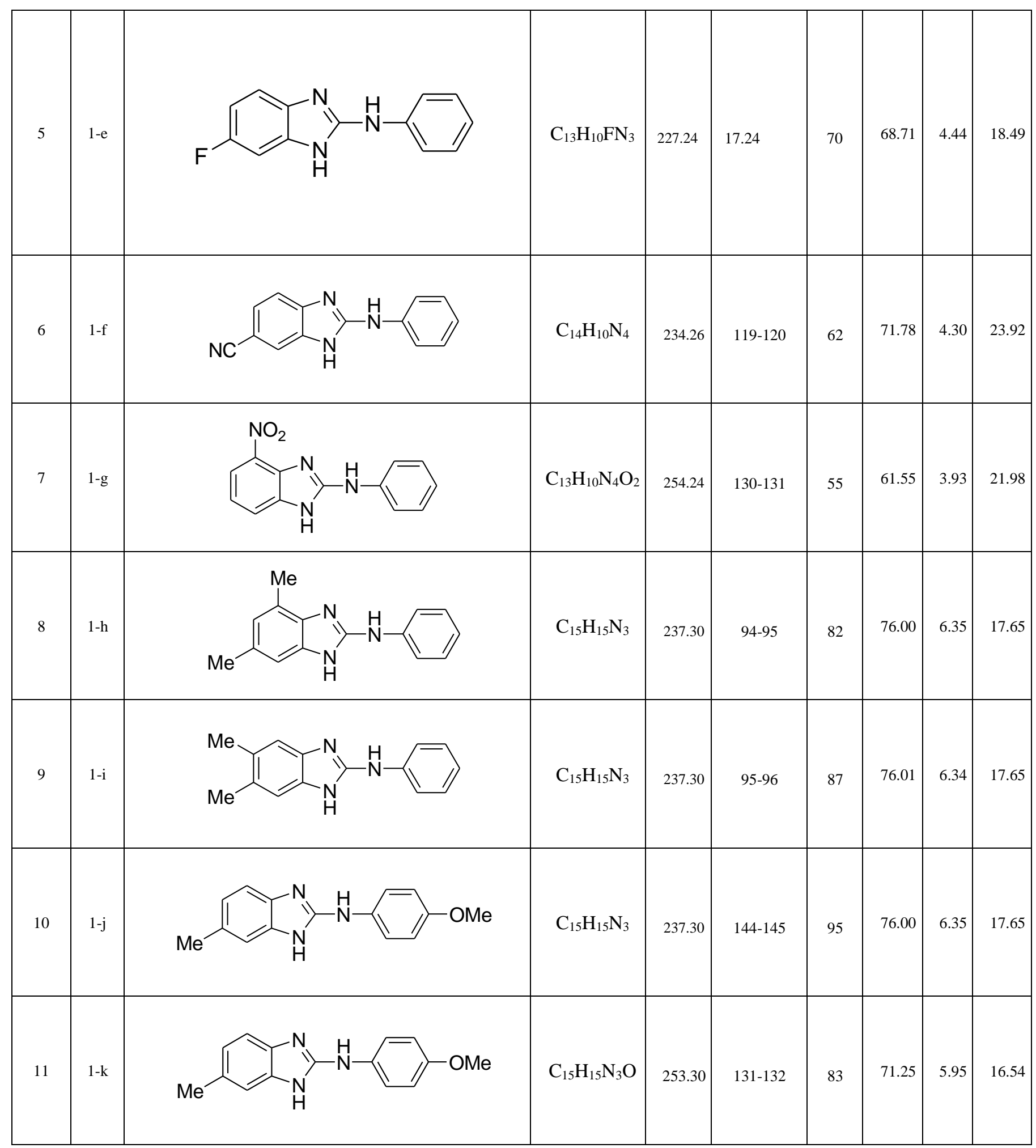

Retrieval Number: K10390741120/2020@BEIESP

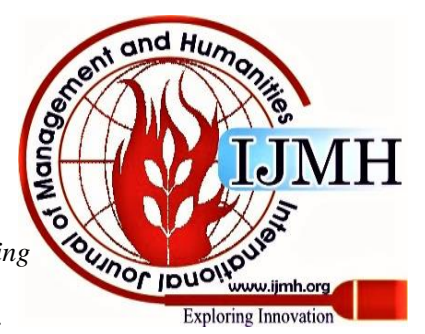




\section{Antimicrobial Activity of Benzimidazoles Derivatives}

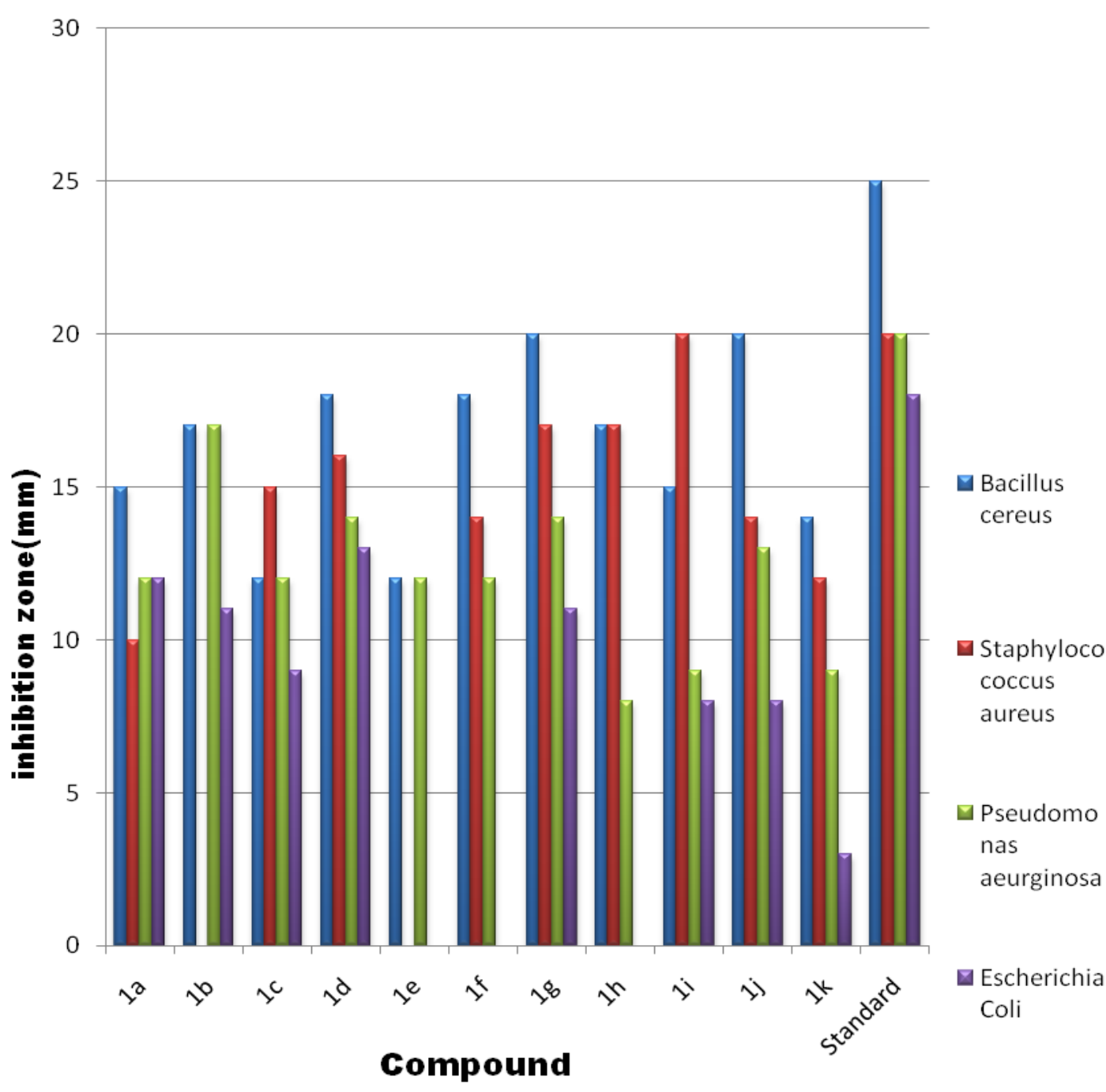

Fig-1.Comparison of antibacterial activities of selected benzimidazoles

\section{CONCLUSION}

Anti-microbial activity was performed on all synthesized compounds. Compound 1-g showed good activity against Bacillus cereus (MTCC 430), Staphylococcus aureus (MTCC 3160), Pseudomonas aeruginosa (MTCC 424) and; Compound 1-i showed good activity against), Staphylococcus aureus (MTCC 3160), and Bacillus cereus (MTCC 430). Compounds 1-a, 1-b 1-d, 1-g, 1-i, and 1-k and exhibited promising antibacterial activity against all the selected bacterial strains at $250 \mu \mathrm{g} / \mathrm{ml}$ dose.

\section{ACKNOWLEDGMENT}

Biological activities of some synthesized substituted 2aminophenyl benzimidazoles were studied using Filter paper disc diffusion method. The authors are highly thankful to I express my sincere thanks to Dr. P. Gopi Krishna, Department of Zoology, Vikram Simhapuri University, Kavali to providing the biological activity studies

\section{REFERENCES}

1. K.Bahrami, M. M.Khodaei, and F.Naali, "Mild and highly efficient method for the synthesis of 2-arylbenzimidazoles and 2-arylbenzothiazoles" J. Org. Chem.73, 2008,pp 6835-6837.

2. R. B.Baudy, H. Fletcher III, J. P.Yardley, M. M.Zaleska, D. R Bramlett, R. P. Tasse, D. M. Kowal, A. H.Katz, J. A. Moyer, and M. Abou-Gharbia, "Design, synthesis, and biological evaluation of highly potent benzimidazole spaced phosphono amino acid competitive antagonists of the AP-6 type" J. Med. Chem.44., 2001, pp1516-1529.

3. Z. S. Zhao, , D. O.Arnaiz, , B.Griedel, , S.,Sakata, J. L. Dallas, , M Whitlow., Trinh, L,Post J.,Liang A.,Morrissey M. .and K.Shaw "Design, synthesis, and in vitro biological activity of benzimidazole based factor Xa inhibitors" J. Bioorg. Med. Chem. Lett. 10, 2000.pp 963-966.

4. A.W.White, A.H. Almassy, N.J.Calvert, R,J. Curtin, Griffin, Z Hostomsky, K.Maegley, D.R. Newell, S. Srinivasan, and B.T. Golding, "Synthesis and biological properties of benzimidazole inhibitors of the DNA repair enzyme poly(ADP-ribose)polymerase" $J$. Med. Chem.43, 2000,pp 4084-4097.

5. H.Zarrinmayeh, A.M. Nunes, L.Ornstein, D.M. Zimmerman, M.B.Arnold, D.A.Schober, S.L. Gackenheimer, F.R. Bruns,P.A., Hipskind,T.C. Britton, B.E. Cantrell, and D. Gehlert, "Synthesis and evaluation of a series of novel 2-[(4-chlorophenoxy)methyl] benzimidazoles as selective neuropeptide YY1 receptor antagonists" $J$. Med. Chem.41, 1998, pp 2709-2719.

6. N.H.Hauel, H. Nar,H. Priepke, U. Ries, J Stassen, and W.Wienen, "Structure-based design of novel potent nonpeptide thrombin inhibitors” J. Med. Chem.,45, 2002, pp 1757-1766.

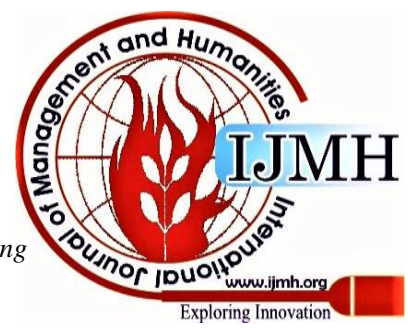




\section{AUTHOR PROFILE}

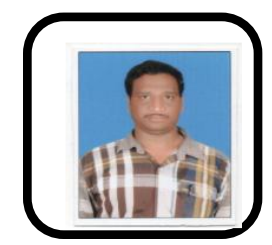

Dr Srinivasa Rao Nathani, M.Sc, Ph,D Assistant Professor.Department of Chemistry. Bapatla Engineering College, Bapatla Andhra Pradesh, India nathanisrinivasarao@gmail.com

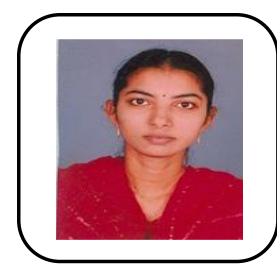

Dr. Lakshmi Kondraganti, M.Sc, Ph,D Working as Ward women and weaker Protection Secretary, Ward -09 Vivekanada colony, Bapatla Municipality, Bapatla, Andhra Pradesh,India

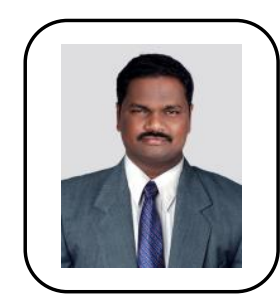

Dr. Mohan Seelam, obtained Ph. D from Acharya Nagarjuna University. Currently working as Assistant Professor in the Department of Chemistry, Bapatla Engineering College, Bapatla, Guntur District, Andhra Pradesh, India

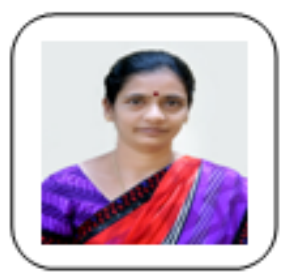

Dr. V. Nagalakshmi, M.Sc.,,M.Phil,;Ph.D Associate Professor in Chemistry Ch.S.D.St.Theresa's College for Women(A), Eluru West Godavari District Andhra Pradesh, Indianlcheruvu@gmail.com

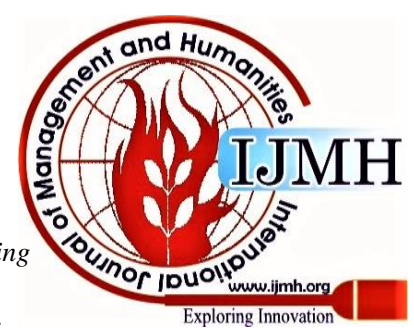

